\title{
Pengaruh Struktur Kepemilikan Terhadap Pengungkapan Corporate Social Responsibility Pada Perusahaan High Profile di BEI
}

\author{
Muhammad Rivandi \\ Sekolah Tinggi Ilmu Ekonomi KBP \\ muhammadrivandi@akbpstie.ac.id
}

\begin{abstract}
Corporate Social Responsibility (CSR) is an important element for the company's success and can provide benefits to the company. The purpose of this study obtained empirical evidence regarding the effect of ownership structure on CSR disclosure. The research population are all high profile companies listed on the IDX. The sample in this study were 42 companies selected by the purposive sampling method. The analysis method used the panel regression method. Based on the hypothesis the results of the study shown that managerial ownership has a negative effect on CSR disclosure, and institutional ownership has a positive effect on CSR disclosure, while public ownership does not effect on CSR disclosure.
\end{abstract}

Keywords: Corporate Social Responsibility, Managerial Ownership, Institutional Ownership, Public ownership

\begin{abstract}
Abstrak
Corporate Social Responsibility (CSR) merupakan salah satu elemen penting bagi keberhasilan perusahaan dan dapat memberikan manfaat bagi perusahaan. Tujuan penelitian ini adalah untuk mendapatkan bukti empiris mengenai pengaruh struktur kepemilikan terhadap pengungkapan CSR. Populasi penelitian adalah semua perusahaan ternama yang terdaftar di BEI. Sampel dalam penelitian ini sebanyak 42 perusahaan yang dipilih dengan metode purposive sampling. Metode analisis yang digunakan adalah metode regresi panel. Berdasarkan hipotesis hasil penelitian menunjukkan bahwa kepemilikan manajerial berpengaruh negatif terhadap pengungkapan CSR, dan kepemilikan institusional berpengaruh positif terhadap pengungkapan CSR, sedangkan kepemilikan publik tidak berpengaruh terhadap pengungkapan CSR.
\end{abstract}

Kata Kunci: Corporate Social Responsibility, kepemilikan manajerial, kepemilikan institusional, kepemilikan publik 


\section{PENDAHULUAN}

Tujuan perusahaan selain untuk mengejar keuntungan atau profit yang maksimal, suatu perusahaan seharusnya juga memperhatikan dan harus ikut andil dalam pemenuhan kesejahteraan masyarakat sekitar lingkungan perusahaan serta turut berkontribusi aktif dalam menjaga kebersihan lingkungan supaya tetap terjaga dengan baik. Hal ini mengisyaratkan bahwa perusahaan boleh berlanjut sebagai suatu instansi pencetak laba dimana dalam hal itu perusahaan tidak melakukan kerusakan lingkungan dan sosial. Setiap substansi harus meningkatkan keberadaan tanggung jawab sosial yang muncul untuk memperkuat keberadaan perusahaan secara keberlanjutan dengan menciptakan kerja sama antar stakeholders terkait.

Menurut Nugroho \& Yulianto (2015) Coporate Social Responsibility merupakan suatu aktivitas perusahaan dalam melakukan tanggung jawabnya kepada para stakeholder yaitu dengan cara memberikan perhatian terhadap lingkungan yang ada di sekitar perusahaan tersebut. Dalam mempertahankan keberlangsungan hidup suatu perusahaan, maka harus berpatokan pada triple bottom lines, yaitu selain untuk memperoleh keuntungan (profit), suatu instansi harus bisa terlibat dalam pemenuhan kesejahteraan masyarakat (people) dan serta juga harus ikut berkontribusi aktif dalam penjagaan kebersihan lingkungan (planet). Pemerintah juga menerbitkan undang-undang mengenai tanggung jawab sosial ini, yaitu UU no. 40 tahun 2007 mengenai Perseroan Terbatas yang mewajibkan setiap perusahaan pada bidang yang terkait dengan sumber daya alam guna untuk menjalankan pertanggungjawaban sosial dan lingkungan (UU No.42, 2007).

Seiring dengan hal diatas tanggung jawab sosial perusahaan atau corporate social responsibility (CSR) menurut Badjuri (2011) yaitu suatu gagasan yang mana dalam halnya membentuk perseroan yang tidak dihadapkan hanya pada pertanggungjawaban sosial yang terfokus pada single bottomline saja, yaitu suatu nilai perusahaan (corporate value) yang dirangkum dalam suatu kondisi keuangan (financial), akan tetapi pertanggungjawaban sosial perusahaan seharusnya berlandaskan pada triple bottom lines yang memperhatikan permasalahan sosial dan lingkungan. Beliau juga menyatakan bahwa korporasi itu bukan hanya sebagai entitas perusahaan yang mementingkan kepentingan pribadi saja sehingga mengakibatkan perusahaan mengasingkan diri dari lingkungan sosial dimana tempat mereka bekerja, melainkan sebagai suatu entitas usaha yang harus melakukan adaptasi kultural terhadap lingkungan sosialnya.

Program CSR pada penelitian ini ditujukan pada instansi perusahaan high profile yang memiliki perkembangan potensi sumber daya alam secara langsung serta memberikan dampak yang besar bagi keberlangsungan hidup manusia dimasa depan. Untuk melakukan pengevaluasian terhadap pelaksanaan program CSR dapat dilihat dari angka indeks pengungkapan yang ada pada masing-masing perusahaan, untuk perusahaan high profile di Indonesia berpedoman pada Global Reporting Initiative (GRI) yaitu berjumlah sebanyak 79 item pengungkapan yang merupakan hasil revisi dari GRI 3.1 tahun 2012 (Rivandi \& Putra, 2019).

Permasalahan Kondisi Alam saat ini seperti gempa bumi, longsor, banjir, kerusakan 
pencemaran sungai dan laut, penebangan hutan secara illegal membuat kerusakan alam, kondisi inilah diperlukan kesadaran perusahaan dalam memperhatikan lingkungan. Oleh karena itu pemerintah mewajibkan semua perusahaan harus dapat melakukan Pengungkapan CSR. Dengan adanya sinergi antar perusahaan dan pemerintah bersama-sama dalam melakukan perbaikan kepada lingkungan akan berdampak baik kepada kondisi alam.

Pengungkapan program CSR tidak terlepas dari struktur kepemilikan yang ada dalam perusahaan, karena masing-masing struktur kepemilikan sangat berperan penting dalam penetapan jumlah pengeluaran CSR. Struktur kepemilikan pada perusahaan diperoleh dari perbandingan jumlah kepemilikan saham yang ada dalam suatu perusahaan. Suatu perusahaan dapat dimiliki oleh pemerintah, seseorang yang secara individu, masyarakat luas, pihak investor asing, maupun orang lain yang berada dalam perusahaan tersebut (manajerial). Perbedaan persentase kepemilikan saham yang dimiliki investor dapat mempengaruhi tingkat kesempurnaan pengungkapan dalam suatu perusahaan. Semakin banyak pihak yang membutuhkan informasi mengenai perusahaan, maka semakin detail pula pengungkapan tanggung jawab sosial yang dilakukan oleh perusahaan. Keterlibatan kepemilikan manajerial didalam perusahaan akan memberikan dampak positif bagi perusahaan dalam mengawasi perusahaan agar dapat menjalankan program CSR.

\section{Kepemilikan Manajerial}

Kepemilikan manajerial yaitu investor yang juga sebagai pemilik perusahaan memiliki tugas serta wewenang dalam pengambilan keputusan pada suatu perusahaan (dewan komisaris dan dewan direksi) (Rivandi, 2018). Kepemilikan Manajerial yaitu besarnya persentase nilai saham yang ada pada pihak manajemen di bagi dengan total saham yang beredar. Pengukuran skala rasio digunakan dalam variabel ini dan kepemilikan manajerial dalam penelitian ini yaitu dengan menghitung persentase jumlah saham yang dimiliki pihak manajemen dari seluruh total modal saham yang beredar (Agustia, 2013). Kepemilikan manajerial merupakan kondisi dimana manajer sebagai investor dalam perusahaan atau manajer tersebut sekaligus sebagai pemegang saham perusahaan (Karima, 2014). Adapun pihak tersebut yaitu mereka yang berkedudukan sebagai dewan komisaris dan dewan direksi perusahaan. Keberadaan manajemen perusahaan mempunyai latar belakang berbeda, yaitu: pertama, mereka yang mewakili pemegang saham institusi, kedua, mereka adalah tenagatenaga profesional yang diangkat oleh pemegang saham dalam Rapat Umum Pemegang Saham. Ketiga, mereka yang duduk di jajaran manajemen perusahaan karena turut memiliki saham. Struktur kepemilikan manajerial dapat diukur sesuai dengan proporsi saham biasa yang dimiliki oleh manajerial (Rivandi \& Gea, 2018).

Berdasarkan penelitian terdahulu yang dilakukan oleh Karima (2014), Priantana \& Yustian (2011) dan Rawi (2008) menemukan bahwa kepemilikan manajerial berpengaruh positif terhadap pengungkapan CSR. Karena dengan semakin besar kepemilikan manajemen di dalam perusahaan, manajer perusahaan akan semakin banyak mengungkapkan informasi sosial. Berbeda dengan penelitian sebelumnya penelitian Priantana \& Yustian (2011) memperoleh hasil penelitian bahwa kepemilikan manajerial berpengaruh negatif 
terhadap pengungkapan CSR. Semakin besar nilai kepemilikan saham manajerial dalam suatu perusahaan maka akan memperkecil pengungkapan CSR yang dilakukan oleh pihak manajemen, dalam hal ini diasumsikan bahwa perusahaan lebih mementingkan kepentingan untuk manajer daripada pihak lain diluar perusahaan.

Penelitian tersebut bertolak belakang dengan penelitian yang dilakukan oleh Waryanto (2010) dan Melati (2014) yang menemukan bahwa kepemilikan manajerial tidak berpengaruh terhadap pengungkapan CSR. Hal ini mengartikan bahwa kepemilikan manajerial memiliki nilai yang relatif kecil, maka masih rentan terjadinya konflik kepentingan antara pemilik dengan pihak manajer perusahaan, dimana kepentingan pribadi manajer belum dapat diselaraskan dengan kepentingan perusahaan atau pemilik. Dengan demikian, dengan kepemilikan saham manajerial yang kecil, tindakan manajer dalam memaksimalkan nilai perusahaan yang selaras dengan kepentingan pemilik untuk melakukan pengungkapan tanggung jawab sosial masih belum dapat dilakukan.

Menurut teori dan hasil penelitian bahwa semakin besar kepemilikan manajerial maka akan semakin banyak pengungkapan CSR yang akan dilakukan. Berarti bahwa dengan adanya kepemilikan saham oleh pihak manajemen, maka manajemen tersebut akan ikut serta aktif dalam pengambilan berbagai keputusan. Berdasarkan teori dan hasil penelitian maka peneliti mengajukan hipotesis yang akan dibuktikan secara empiris:

$\mathbf{H}_{\mathbf{1}}$ : Kepemilikan manajerial berpengaruh positif terhadap pengungkapan Corporate Social Responsibility.

\section{Kepemilikan Institusional}

Kepemilikan institusional adalah jumlah kepemilikan saham oleh pihak-pihak yang berbentuk institusi, seperti bank, perusahaan investasi, dana pensiun, perusahaan asuransi, dan institusi lainnya. Pemegang saham institusional juga memiliki opportunity, resources, dan expertise untuk menganalisis kinerja dan tindakan manajemen. Investor institusional sebagai pemilik sangat berkepentingan untuk membangun reputasi perusahaan (Agustia, 2013). Menurut Karima (2014) kepemilikan institusional adalah kepemilikan saham perusahaan oleh pihak institusi (badan). Tingkat kepemilikan institusional yang tinggi akan membentuk suatu usaha pengawasan yang lebih besar dari pihak investor institusional sehingga dapat mengurangi perilaku opportunistic manajer.

Berdasarkan penelitian yang dilakukan oleh Soliman et al. (2012), Nugroho \& Yulianto (2015) dan Sari, Sutrisno \& Sukoharsono (2013) menemukan bahwa kepemilikan institusional mempunyai pengaruh positif terhadap pengungkapan CSR. Hal ini disebabkan besarnya kepemilikan institusional merupakan entitas perbankan, asuransi, dana pensiun, reksa dana, dan institusi lain yang mempunyai kecenderungan untuk berinvestasi dalam rangka mendapatkan keuntungan, sehingga tingkat kepemilikan institusional yang tinggi menimbulkan usaha pengawasan yang lebih besar untuk menghalangi perilaku oportunistis manajer tidak dapat berjalan optimal. Berbeda dengan itu, Waryanto (2010) yang memperoleh hubungan negatif antara kepemilikan saham institusional dengan luas pengungkapan CSR. Artinya semakin tinggi tingkat kepemilikan institusional, maka akan 
mengurangi tingkat pengungkapan tanggung jawab sosial yang dilakukan perusahaan. Namun penelitian yang dilakukan oleh Rochayatun (2016) dan Husna, Uzaimi, \& Trisna (2017) menemukan bahwa kepemilikan institusional tidak berpengaruh terhadap pengungkapan CSR. Mereka mengemukakan bahwa kepemilikan institusional di Indonesia belum menjadi pertimbangan yang serius dalam tanggung jawab sosial sebagai salah satu kriteria dalam melakukan investasi sehingga para investor institusi ini cenderung tidak menekan perusahaan untuk mengungkapkan CSR secara detail dalam laporan tahunan perusahaan.

Menurut teori dan hasil penelitian terdahulu diperoleh bahwa makin besar kepemilikan saham institusional pada perusahaan maka tekanan terhadap pihak manajemen perusahaan untuk mengungkapkan pertanggungjawaban sosial pun semakin besar. Institusi seperti pemerintah merupakan salah satu instansi yang kuat dalam membuat kebijakan terkait CSR yang mengawasi manajemen perusahaan untuk melaksanakan kebijakan CSR secara lebih baik. Berdasarkan beberapa asumsi tersebut, maka peneliti mengajukan hipotesis yang akan dibuktikan secara empiris:

$\mathbf{H}_{2}$ : Kepemilikan institusional berpengaruh positif terhadap pengungkapan Corporate Social Responsibility

\section{Kepemilikan Publik}

Menurut Nur \& Priantinah (2012) Kepemilikan publik itu adalah dimana segala aktivitas serta keadaan perusahaan yang harus dilaporkan dan diketahui oleh pihak publik sebagai salah satu bagian pemegang saham. Perusahaan yang sebagian besar sahamnya dimiliki oleh Publik, biasanya lebih sering menghadapi masalah asimetri informasi dikarenakan hambatan geografis dan bahasa. Menurut Soejoto (2017) kepemilikan publik yaitu kepemilikan saham yang dimiliki oleh pihak investor individual diluar manajemen yang tidak memiliki hubungan istimewa dengan perusahaan. Kepemilikan publik menggambarkan tingkat kepemilikan oleh perusahaan oleh masyarakat publik. Besarnya kepemilikan saham individual ini biasanya di bawah 5\%, sehingga investor tidak memiliki kendali atas perusahaan. Oleh sebab itu, investor publik memerlukan perlindungan atas saham yang mereka tanam, perlindungan ini dapat berupa pengungkapan informasi keuangan dan non-keuangan pada perusahaan tahunan yang berguna dalam pengambilan keputusan.

Penelitian yang dilakukan oleh Fatkhiyatur (2016), Soejoto (2017) dan Rahmayanty (2015) menemukan bahwa kepemilikan saham publik berpengaruh positif terhadap pengungkapan tanggung jawab sosial. Perusahaan yang mempunyai tingkat kepemilikan publik lebih tinggi akan cenderung melakukan lebih banyak pengungkapan sosial karena dinilai memiliki tanggung jawab secara moral kepada masyarakat. Penelitian yang dilakukan Agustia (2013) dan Ratmelia (2015) menemukan bahwa tidak adanya pengaruh antara kepemilikan saham publik terhadap pengungkapan CSR. Dikarenakan kepemilikan publik pada perusahaan yang ada di Indonesia secara umum masih belum memperdulikan permasalahan lingkungan dan sosial sebagai isu kritis yang harus secara ekstensif untuk diungkapkan dalam laporan tahunan. 
Pemegang saham publik yaitu pihak yang tidak memiliki kendali apapun atas perusahaan. Pemegang saham publik hanya membutuhkan perlindungan atas investasi yang telah mereka tanam, perlindungan ini dapat berupa pengungkapan informasi keuangan dan non-keuangan pada laporan tahunan yang bermanfaat untuk pengambilan keputusan. Semakin tinggi proporsi kepemilikan saham yang dimiliki publik maka tingkat kelengkapan pengungkapan pada laporan tahunan akan semakin tinggi pula. Berdasarkan asumsi tersebut, maka peneliti mengajukan hipotesis sebagai berikut:

$\mathbf{H}_{3}$ : Kepemilikan publik berpengaruh positif terhadap pengungkapan Corporate Social Responsibility.

\section{METODE}

\section{Populasi dan Sampel}

Populasi pada penelitian ini adalah seluruh perusahaan high profile yang terdaftar di Bursa Efek Indonesia tahun 2014-2018. Teknik pengambilan sampel yang digunakan adalah teknik sampling secara non-probabilitas, dengan teknik pengambilan sampel yaitu Purposive Sampling yang didasarkan dari pemilihan kriteria-kriteria yang mempunyai keterkaitan dengan karakteristik yang telah diketahui sebelumnya yaitu 1) Perusahaan yang memiliki status high profile yang listed di BEI yaitu meliputi: makanan dan minuman, automotive, industri batubara, pengolahan batu-batuan, logam mulia serta minyak dan gas. 2) Perusahaan yang menerbitkan laporan keuangan tahunan selama periode penelitian dari tahun 2014-2018. 3) Perusahaan yang tidak delisting pada periode penelitian tahun 2014-2018. 4) Perusahan yang mempunyai laba positif selama periode penelitian tahun 2014-2018.

Populasi sebanyak 125 perusahaan high profile tahun 2014-2018, sebanyak 42 perusahaan dipilih karena lolos dalam pemilihan kriteria. Berikut adalah gambaran pemilihan sampel perusahaan:

\section{Tabel 1 Kriteria Proposive sampling}

\begin{tabular}{clc}
\hline No & \multicolumn{1}{c}{ Keterangan } & Total \\
\hline 1 & Jumlah perusahaan High profile di Bursa Efek Indonesia pada periode 2014-2018 & 125 \\
2 & $\begin{array}{l}\text { Perusahaan yang tidak mempunyai laporan keuangan tahunan (Annual Report) } \\
\text { secara lengkap periode 2014-2018 }\end{array}$ & $(42)$ \\
3 & Perusahaan yang delesting pada periode penelitian & 0 \\
$4 \quad$ Perusahaan yang mengalami kerugian pada tahun buku 2014-2018 & $(41)$ \\
Jumlah perusahaan sampel yang digunakan & 42 \\
Jumlah tahun penelitian & 5 \\
Sampel akhir & 210 \\
\hline
\end{tabular}

Sumber: Hasil Pengolahan Data, 2018 


\section{Definisi Operasional Variabel}

Variabel dependent pada penelitian ini adalah Corporate Social Responsibility, sedangkan variabel independentnya yaitu kepemilikan manajerial, kepemilikan institusional dan kepemilikan publik.

Berikut disajikan definisi operasional dalam penelitian ini:

Tabel 2 Operasional Variabel

\begin{tabular}{|c|c|c|}
\hline Variabel & Definisi & Pengukuran \\
\hline $\begin{array}{l}\text { Pengungkapan } \\
\text { Corporate Social } \\
\text { Responsibility }\end{array}$ & $\begin{array}{l}\text { Salah satu elemen penting dalam meningkatkan } \\
\text { efisiensi ekonomis, yang meliputi serangkaian } \\
\text { hubungan antara manajemen perusahaan, } \\
\text { dewan komisaris, para pemegang saham, dan } \\
\text { stakeholder lainnya (Agustia,2013) }\end{array}$ & $\begin{array}{c}\begin{array}{c}\text { Pengungkapan CSR }= \\
\text { (jumlah pengungkapan CSR) }\end{array} \\
\text { (total pengkapan CSR) }\end{array}$ \\
\hline Kepemilikan Manajerial & $\begin{array}{l}\text { Persentase saham yang dimiliki oleh eksekutif } \\
\text { dan direktur (Melati, 2014) }\end{array}$ & $\begin{array}{l}\text { Kepemilikan Manajerial = } \\
\frac{\text { jumlah kepemilikan saham manajerial }}{\text { jumlah saham beredar }}\end{array}$ \\
\hline $\begin{array}{l}\text { Kepemilikan } \\
\text { Institusional }\end{array}$ & $\begin{array}{l}\text { Kepemilikan saham perusahaan yang dimiliki } \\
\text { oleh pemerintah, institusi keuangan, seperti } \\
\text { bank, perusahaan asuransi, dana pensiun, } \\
\text { dan kepemilikan institusi lain (Nugroho \& } \\
\text { Yulianto, 2015) }\end{array}$ & $\begin{array}{l}\text { Kepemilikan Institusional }= \\
\frac{\text { jumlah kepemilikan saham institusional }}{\text { jumlah saham beredar }}\end{array}$ \\
\hline Kepemilikan Publik & $\begin{array}{l}\text { Kepemilikan saham dimana semua aktivitas } \\
\text { dan keadaan perusahaan harus dilaporkan dan } \\
\text { diketahui oleh publik sebagai salah satu bagian } \\
\text { pemegang saham (Nur \& Priantinah, 2012) }\end{array}$ & $\begin{array}{l}\text { Kepemilikan Publik = } \\
\frac{\text { jumlah kepemilikan saham publik }}{\text { jumlah saham beredar }}\end{array}$ \\
\hline
\end{tabular}

\section{Teknik analisis data}

Pembuktian mengenai kebenaran hipotesis maka digunakan metode analisis dengan cara kuantitatif, dilakukan menggunakan pembentukan metode pengujian kelayakan Model Effect Regresi Panel yaitu Regresi Fixed Effect Model Dan Random Effect Model. Winarno (2009) mengungkapkan secara umum model panel regresi yang digunakan mengetahui arah dan besarnya pengaruh variabel independen terhadap variabel dependen secara individual. Model regresi yang akan dibentuk dan dianalisis maka terlebih dahulu dilakukan pengujian kelayakan pada model regresi panel.

$$
\mathrm{Y}_{\mathrm{it}}=\beta_{0}+\beta_{1} \mathrm{X}_{\mathrm{it}}+\beta_{2} \mathrm{X}_{2 \mathrm{it}}+\beta_{3} \mathrm{X}_{3 \mathrm{it}}+\mathrm{e}
$$

Berdasarkan model regresi panel dapat di jelaskan bahwa $Y_{i t}$ merupakan Jumlah Pengungkapan CSR, $\mathrm{X}_{\mathrm{it}}$ merupakan Kepemilikan Manajerial tahun tertentu, $\mathrm{X}_{2 \mathrm{it}}$ merupakan Kepemilikan Institusional pada tahun tertentu, $\mathrm{X}_{3 \mathrm{it}}$ merupakan Kepemilikan Publik tahun tertentu dan $\beta_{0}$ merupakan konstanta bila $\mathrm{X}=0$

\section{HASIL DAN PEMBAHASAN}

Statistik deskriptif variabel penelitian ini disesuaikan dengan rumusan masalah dan hipotesis yang ada, tujuan dilakukannya penelitian ini yaitu untuk memperoleh bukti 
empiris mengenai pengaruh Struktur kepemilikan yaitu Kepemilikan Manajerial, Kepemilikan Institusional dan Kepemilikan Publik terhadap Pengungkapan CSR pada Perusahaan High profile di Bursa Efek Indonesia. Data observasi yang digunakan didalam penelitian ini yaitu dari tahun 2014 sampai dengan tahun 2018. Perusahaan yang digunakan berjumlah 42 perusahaan yang digolongkan kepada perusahaan high profile di Bursa Efek Indonesia. Proses pengolahan data yang dilakukan dengan metode pengaplikasian Eviews 8. Berdasarkan proses pengolahan data tersebut dapat dinarasikan statistik deskriptif variabel penelitian seperti pada tabel 3 berikut ini:

Tabel 3 Statistik Deskriptif Variabel Penelitian

\begin{tabular}{lccccc}
\hline Variabel Penelitian & N & Minimum & Maksimum & Rata-Rata & $\begin{array}{c}\text { Std. } \\
\text { Deviasi }\end{array}$ \\
\hline Pengungkapan CSR & 210 & 22,78 & 92,41 & 63,94 & 13,26 \\
Kepemilikan Manajerial & 210 & 0,00 & 77,61 & 4,16 & 12,93 \\
Kepemilikan Institusional & 210 & 0,36 & 92,66 & 47,63 & 23,47 \\
Kepemilikan Publik & 210 & 0,59 & 70,60 & 28,69 & 16,33 \\
\hline
\end{tabular}

Sumber: Hasil Pengolahan Data, 2018

Berdasarkan tabel 3 diperoleh total nilai observasi data yang diolah dalam penelitian ini sebanyak 210 observasi yang tersebar dalam 5 tahun penelitian. Sepanjang periode penelitian antara tahun 2014 sampai 2018 jumlah pengungkapan CSR terendah yaitu $22,78 \%$ sedangkan jumlah pengungkapan CSR tertinggi mencapai 92,41\%. Secara keseluruhan jumlah pengungkapan CSR rata-rata yang dimiliki seluruh perusahaan high profile di BEI mencapai 63,94\% pengungkapan CSR dengan standar deviasi data sebesar 13,26\%.

Kepemilikan manajerial sepanjang tahun 2014 sampai 2018 terlihat bahwa nilai kepemilikan manajerial terendah yaitu sebesar 0,00\%. Sedangkan nilai kepemilikan institusional tertinggi adalah sebesar $77,61 \%$. Secara menyeluruh nilai kepemilikan ratarata yang diperoleh pada umumnya perusahaan high profile di BEI adalah 4,16\% dengan standar deviasi sebesar 12,93\%.

Kepemilikan institusional selama tahun penelitian yaitu dari tahun 2014 hingga 2018 terlihat bahwa nilai kepemilikan institusional terendah yang diperoleh perusahaan yaitu sebesar 0,36\%, sedangkan nilai kepemilikan institusional tertinggi yaitu mencapai 92,66\%. Secara keseluruhan rata-rata profitabilitas yang dimiliki perusahaan high profile yang menjadi sampel mencapai 47,63\% dengan standar deviasi data sebesar 23,47\%.

Pada tabel 3 juga terlihat bahwa sepanjang tahun 2014 sampai 2018 nilai kepemilikan publik yang terendah yaitu sebesar 0,59\% sedangkan nilai tertinggi adalah sebesar 70,60\%, secara keseluruhan rata-rata kepemilikan publik mencapai $28,69 \%$ dengan standar deviasi data mencapai $16,33 \%$. 


\section{Pengujian Kelayakan Model Regresi Panel}

\section{Pengujian Hausman test}

Pengujian prasyarat yang diterima menggunakan model Regresi Random dengan pengujian Hausman Test. Didalam pengujian Hausman Test, Random Effect Model (REM) dapat diterima bila nilai F-probability yang dihasilkan didalam pengujian berada diatas 0,05. Berdasarkan hasil pengujian yang telah dilakukan diperoleh ringkasan hasil terlihat pada tabel 4 berikut:

Tabel 4 Hasil Pengujian Hausman Test

\begin{tabular}{cccc}
\hline Test Summary & Chi-Sq. Statistic & Chi-Sq. d.f. & Prob. \\
\hline Cross-section random & 1.692534 & 3 & 0.6386 \\
\hline
\end{tabular}

Sumber: Hasil Pengolahan Data 2018

Berdasarkan hasil pengujian yang telah dilakukan diperoleh nilai probability sebesar 0,6386, proses pengolahan dilakukan dengan menggunakan tingkat kesalahan yaitu 0,05. Hasil yang diperoleh pada pengujian Husman Test menunjukkan bahwa nilai probability sebesar 0,6386 $\geq$ alpha 0,05 maka dapat disimpulkan penggunaan Random Effect Model (REM) didalam model penelitian saat ini baik dan layak untuk digunakan.

\section{Regresi Random Effect Model}

Berdasarkan pengujian dalam pembentukan model maka peneliti mengambil keputusan memilih regresi Random Effect Model (REM). Peneliti melihat model regresi REM memiliki nilai probability dan nilai hubungan pengaruh variabel independen terhadap pengungkapan CSR lebih tinggi dibandingkan model regresi Fixed Effect Model (FEM), oleh karena itu peneliti memilih menggunakan pembentukan model regresi effect model di dalam model analisis regresi panel didalam penelitian. Berikut ini adalah hasil pengujian regresi yang dilakukan:

Tabel 5 Hasil Pengujian Regresi Random Effect Model

\begin{tabular}{ccccccc}
\hline Variable & Coefficient & Std. Error & t-Statistic & Prob. & Alpha & Kesimpulan \\
\hline C & 66.13701 & 2.127146 & 31.09191 & 0.0000 & 0,05 & \\
KM & -0.157467 & 0.041779 & -3.769029 & 0.0002 & 0,05 & Signifikan \\
KI & 0.100762 & 0.028448 & 3.541905 & 0.0005 & 0,05 & Signifikan \\
KP & -0.019881 & 0.039666 & -0.501214 & 0.6168 & 0,05 & Tidak signifikan \\
\hline
\end{tabular}

Sumber: Hasil Pengolahan 2018

Sesuai dengan hasil pengujian pada tabel 5 , terlihat masing-masing variabel independen telah memiliki koefisien regresi panel yang dapat dibuat kedalam sebuah model regresi panel dengan menggunakan model Random Effect Model terlihat dibawah ini:

$$
Y_{\text {it }}=66,137-0,157 X_{1 i t}+0,101 X_{2 i t}-0,020 X_{3 i t}
$$


Di dalam model persamaan regresi panel juga terlihat bahwa variabel kepemilikan manajerial memiliki nilai koefisien regresi bertanda negatif sebesar 0,157. Nilai koefisien yang diperoleh menunjukkan bahwa ketika diasumsikan terjadi peningkatan nilai kepemilikan manajerial yang dimiliki perusahaan high profile sebesar 1\% akan menurunkan nilai CSR sebesar 0,157 dengan asumsi faktor lain selain kepemilikan manajerial dianggap tetap atau konstan.

Pada model regresi panel yang telah terbentuk juga teridentifikasi bahwa variabel kepemilikan institusional memiliki koefisien regresi bertanda positif sebesar 0,101. Nilai koefisien yang diperoleh menunjukkan bahwa ketika diasumsikan terjadi peningkatan nilai kepemilikan institusional yang dimiliki perusahaan high profile sebesar $1 \%$ akan meningkatkan nilai CSR sebesar 0,101 dengan asumsi faktor lain selain kepemilikan manajerial dianggap tetap atau konstan.

Berdasarkan model persamaan regresi panel yang telah terbentuk terlihat bahwa variabel kepemilikan publik memiliki koefisien regresi bertanda negatif sebesar 0,020. Nilai koefisien yang diperoleh menunjukkan bahwa ketika diasumsikan terjadi peningkatan nilai kepemilikan publik yang dimiliki perusahaan high profile sebesar 1\% akan menurunkan nilai CSR sebesar 0,020 dengan asumsi faktor lain selain kepemilikan manajerial dianggap tetap atau konstan.

\section{Pengujian Koefisien Determinasi}

Tabel berikut ini menyajikan hasil pengujian koefisien determinasi yang dilakukan pada penelitian ini:

Tabel 6 Hasil Pengujian Koefisien Determinasi (Uji R)

\begin{tabular}{cc}
\hline Keterangan & Koefisien \\
\hline R-Square & 0,1134 \\
Adjust R-Square & 0,1005 \\
\hline
\end{tabular}

Sumber: Hasil Pengolahan Data 2018

Berdasarkan hasil pengujian koefisien determinasi diperoleh nilai Adjust R-square sebesar 0,1005 hasil yang diperoleh tersebut mengisyaratkan bahwa variabel kepemilikan manajerial, kepemilikan institusional dan kepemilikan publik memiliki variasi kontribusi dalam mempengaruhi pengungkapan CSR sebesar 10,05\%. Sedangkan sisanya 89,95\% lagi dijelaskan oleh variabel lain yang belum digunakan didalam penelitian saat ini.

\section{Pengujian Hipotesis}

\section{Pengaruh Kepemilikan Manajerial Terhadap Pengungkapan Corporate Social Responsibility Pada Perusahaan High Profile di Bursa Efek Indonesia}

Berdasarkan hasil pengujian hipotesis pertama yaitu variabel Kepemilikan Manajerial diperoleh nilai probability sebesar 0,0002. Didalam tahapan pengujian digunakan tingkat kesalahan sebesar 0,05. Hasil yang diperoleh menunjukkan bahwa nilai signifikan sebesar 
0,0002 S alpha 0,05 maka keputusannya adalah $\mathrm{H}_{0}$ ditolak, $\mathrm{H}_{\mathrm{a}}$ diterima sehingga dapat disimpulkan bahwa kepemilikan manajerial berpengaruh negatif dan signifikan terhadap pengungkapan CSR pada perusahaan high profile di Bursa Efek Indonesia. Hal ini mengisyaratkan bahwa semakin kecil nilai kepemilikan manajerial dalam suatu perusahaan akan mendorong peningkatan pengungkapan Corporate Social Responsibility pada perusahaan high profile di Bursa Efek Indonesia.

Temuan yang diperoleh dalam tahapan pengujian hipotesis pertama ini sejalan dengan pendapat atau teori yang diungkapkan oleh Ratnawati (2010) yang mengungkapkan bahwa semakin kecil tingkat kepemilikan manajemen, maka semakin besar perusahaan mengeluarkan program CSR. Hal tersebut karena semakin banyak manajemen memiliki saham pada perusahaan bisa menimbulkan adanya perbedaan kepentingan antara pemegang saham (sebagai prinsipal) dengan pihak manajemen sebagai agen. Pertentangan dan tarik menarik kepentingan antara prinsipal dan agen dapat menimbulkan permasalahan yang dalam Agency Theory dikenal sebagai Asymmetric Information (AI) yaitu informasi yang tidak seimbang yang disebabkan karena adanya distribusi informasi yang tidak sama antara prinsipal dan agen. Ketergantungan pihak eksternal pada angka akuntansi, kecenderungan manajer untuk mencari keuntungan sendiri dan tingkat Asymmetric Information yang tinggi menyebabkan keinginan besar bagi manajer untuk memanipulasi kerja yang dilaporkan untuk kepentingan diri sendiri (Ratnawati, 2010).

Hasil penelitian ini sesuai dengan penelitian yang dilakukan oleh Priantana \& Yustian (2011), Maulidra (2015) dan Ratnawati (2010) bahwa kepemilikan manajerial berpengaruh negatif terhadap pengungkapan CSR. Hal tersebut terjadi karena apabila kepemilikan manajerial kecil, maka pengungkapan CSR akan lebih terfokus, tapi sebaliknya bila semakin besar kepemilikan manajerial dalam suatu perusahaan maka akan menyebabkan semakin kecilnya pengungkapan CSR yang dilakukan oleh pihak manajemen, yang diasumsikan bahwa perusahaan lebih mementingkan kepentingan untuk manajer daripada pihak lain diluar perusahaan.

Hasil penelitian ini dapat diinterpretasikan kepemilikan saham manajerial pada perusahaan high profile yang terdaftar pada Bursa Efek Indonesia secara keseluruhan memiliki rata-rata jumlah kepemilikan sebesar 4,16\%, kepemilikan manajerial yang dimiliki perusahaan high profile di BEI secara keseluruhan menunjukkan persentase kepemilikan yang rendah, dengan jumlah kepemilikan manajerial yang kecil mampu untuk mengungkapkan program CSR.

Kepemilikan saham manajerial yang kecil pada perusahaan high profile akan meningkatkan luas pengungkapan tanggungjawab sosial. Kecilnya kepemilikan manajerial dipandang akan membawa respons yang lebih terhadap pihak lain diluar perusahaan, sehingga para pemegang saham manajerial dalam perusahaan high profile lebih fokus untuk menjalankan tugasnya dan mampu untuk mengungkapkan program CSR. Kepemilikan saham oleh pihak manajemen akan menimbulkan suatu pengawasan terhadap kebijakankebijakan yang diambil oleh manajemen perusahaan. Jadi, dalam menjalankan tugasnya pihak manajer lebih fokus untuk melakukan pengungkapan tanggung jawab sosial. Kepemilikan manajerial di dalam perusahaan high profile mempunyai jiwa memiliki 
terhadap perusahaan sehingga memberikan kontribusi yang besar terhadap lingkungan sekitar.

Kepemilikan manajerial yang kecil akan lebih memfokuskan pihak manajer dalam pengungkapan tanggung jawab sosialnya dengan baik, hal tersebut dikarenakan pihak manajer lebih terfokus terhadap tugasnya dalam perusahaan, dengan kepemilikan manajerial yang kecil pengelolaannya lebih mudah dilakukan dan pengungkapan tanggung jawab sosialnya dapat terlaksana dengan baik dan maksimal. Bila kepemilikannya lebih besar maka kemungkinan untuk melaksanakan tanggung jawab sosialnya akan berkurang.

\section{Pengaruh Kepemilikan Institusional Terhadap Pengungkapan Corporation Sosial Responsibility Pada Perusahaan High Profile di Bursa Efek Indonesia}

Sesuai dengan hasil pengujian hipotesis yang kedua menggunakan variabel Kepemilikan Institusional memperoleh nilai probability dari pengujian t- statistik sebesar 0,0005. Proses pengolahan data dilakukan degan menggunakan tingkat kesalahan sebesar 0,05. Hasil yang diperoleh tersebut menunjukkan bahwa nilai probability sebesar 0,0005 $\leq$ alpha 0,05 maka keputusannya adalah $\mathrm{H}_{0}$ ditolak, $\mathrm{H}_{\mathrm{a}}$ diterima sehingga dapat disimpulkan bahwa kepemilikan institusional berpengaruh positif dan signifikan terhadap pengungkapan CSR pada perusahaan high profile di Bursa Efek Indonesia. Hasil penelitian ini mengisyaratkan bahwa semakin besar nilai kepemilikan saham institusional dalam perusahaan dapat mendorong peningkatan efektivitas manajemen didalam melaksanakan kegiatan produksi sekaligus mendorong jumlah pengungkapan CSR yang lebih baik.

Hasil penelitian ini sesuai dengan penelitian Edison (2017), Nugroho \& Yulianto (2015) dan Fifka (2015) yang menemukan bahwa kepemilikan institusional berpengaruh positif terhadap pengungkapan CSR. Hal ini dikarenakan semakin besar kepemilikan institusional maka luas pengungkapan CSR semakin tinggi. Tingkat kepemilikan institusional yang tinggi dalam perusahaan high profile yang merupakan bagian dari entitas perbankan, asuransi, dana pensiun, reksa dana, dan institusi lain yang mempunyai kecenderungan untuk berinvestasi dalam rangka mendapatkan keuntungan, sehingga tingkat kepemilikan institusional yang tinggi akan menimbulkan usaha pengawasan yang lebih besar untuk menghalangi perilaku opportunistic manajer yang tidak berjalan optimal.

Hasil penelitian ini dapat diinterpretasikan bahwa kepemilikan saham institusional pada perusahaan high $p$ rofile yang terdaftar pada Bursa Efek Indonesia. Secara keseluruhan memiliki rata-rata jumlah kepemilikan saham sebesar 47,63\%, kepemilikan institusional yang dimiliki perusahaan high profile di BEI secara keseluruhan menunjukkan persentase yang cukup tinggi, dengan jumlah kepemilikan institusional yang besar mampu untuk mengungkapkan program CSR.

Tingkat kepemilikan institusional yang tinggi menimbulkan usaha pengawasan yang lebih besar untuk menghalangi perilaku opportunistic manajer, sehingga kepemilikan institusional dalam perusahaan high profile dapat meningkatkan kualitas dan kuantitas pengungkapan secara sukarela. Hal ini berarti kepemilikan institusional dapat mendorong perusahaan untuk meningkatkan pengungkapan CSR. Pengawasan yang baik akan pelaksana bila kepemilikan 
institusionalnya maksimal, karena dapat menghalangi perilaku opportunistic manajer, sehingga kualitas dan kuantitas pengungkapan CSR secara sukarela dapat terlaksana dengan baik dan maksimal pula. Kepemilikan institusional yang maksimal adalah kunci perusahaan untuk dapat mendorong peningkatan efektivitas manajemen didalam melaksanakan kegiatan produksi sekaligus mendorong jumlah pengungkapan CSR yang lebih baik.

\section{Pengaruh Kepemilikan Publik Terhadap Pengungkapan Corporate Social Responsibility Pada Perusahaan High Profile di Bursa Efek Indonesia}

Pada tahapan pengujian hipotesis ketiga dengan menggunakan variabel kepemilikan publik diperoleh hasil pengujian t-statistik dengan nilai probability sebesar 0,6168. Proses pengujian data secara statistik dilakukan dengan menggunakan tingkat kesalahan sebesar 0,05 . Hasil yang diperoleh menunjukkan bahwa nilai probability sebesar 0,6168 $\geq$ alpha 0,05 maka keputusannya adalah $\mathrm{H}_{0}$ diterima, $\mathrm{H}_{\mathrm{a}}$ ditolak sehingga dapat disimpulkan bahwa kepemilikan publik tidak berpengaruh terhadap pengungkapan CSR pada perusahaan high profile di Bursa Efek Indonesia. Hal ini mengisyaratkan bahwa besar atau kecilnya kepemilikan saham publik dalam suatu perusahaan tidak memengaruhi pengungkapan CSR.

Hasil yang diperoleh dalam tahapan pengujian hipotesis ketiga ini sejalan dengan teori yang dijelaskan oleh Rindawati \& Asyik (2015), Agustia (2012) dan Badjuri (2011) bahwa kepemilikan publik tidak memiliki pengaruh terhadap pengungkapan CSR. Hal ini menunjukkan bahwa besar kecilnya tingkat kepemilikan publik yang dimiliki oleh perusahaan tidak memiliki pengaruh terhadap pengungkapan CSR. Hal ini bisa terjadi karena persentase kepemilikan publik pada perusahaan yang menjadi sampel dalam penelitian ini tingkat persentase kecil yakni rata- rata $\leq 5 \%$, sehingga publik tidak berpengaruh besar pada nilai pengungkapan CSR, dikarenakan dengan kepemilikan saham yang kecil, publik tidak memiliki otoritas penuh dalam mempengaruhi nilai pengungkapan CSR yang dilakukan perusahaan.

Hasil penelitian ini dapat di interpretasikan bahwa kepemilikan saham publik pada perusahaan high profile yang terdaftar pada Bursa Efek Indonesia. Secara keseluruhan memiliki rata-rata jumlah kepemilikan saham sebesar 28,69\%, kepemilikan publik yang dimiliki perusahaan high profile di BEI secara keseluruhan menunjukkan persentase yang rendah, namun dengan jumlah kepemilikan institusional yang besar ataupun kecil tidak mampu untuk mengungkapkan program CSR. Hal ini dikarenakan bahwa kurangnya perhatian perusahaan terhadap pemegang saham. Kepemilikan saham yang salah satunya adalah pemegang saham retail (skala kecil) yang mana mereka kurang dalam menjalankan fungsi dari monitoring dan tidak menekan pada perusahaan yang berkaitan dengan kegiatan CSR.

Tinggi atau rendahnya kepemilikan saham publik dalam perusahaan high profile tidak mempengaruhi dalam pengungkapan CSR. Hal ini dapat diindikasikan kepemilikan saham publik (investor) kemungkinan tidak dilibatkan dalam pengambilan keputusan untuk melaksanakan pengungkapan CSR. Kemungkinan kepemilikan publik pada perusahaan high profile di Indonesia secara umum belum mempedulikan masalah lingkungan dan sosial sebagai isu kritis yang harus secara ekstensif untuk diungkapkan dalam laporan tahunan. 


\section{SIMPULAN}

Berdasarkan pada analisis dan pembahasan hasil pengujian hipotesis yang telah dijelaskan maka dapat diajukan beberapa kesimpulan penting yang merupakan jawaban dari permasalahan yang dibahas dalam penelitian ini yaitu: 1) Kepemilikan manajerial yang diukur dengan total persentase jumlah kepemilikan manajerial berpengaruh negatif dan signifikan terhadap pengungkapan CSR pada perusahaan high profile di Bursa Efek Indonesia. Semakin rendah kepemilikan manajerial maka semakin tinggi tingkat pengungkapan CSR. 2) Kepemilikan institusional yang diukur dengan total persentase jumlah kepemilikan institusional berpengaruh positif dan signifikan terhadap pengungkapan CSR pada perusahaan high profile di Bursa Efek Indonesia. Semakin tinggi kepemilikan institusional akan semakin mendorong peningkatan pengungkapan CSR pada perusahaan high profile di Bursa Efek Indonesia. 3) Kepemilikan publik yang diukur dengan total persentase jumlah kepemilikan publik tidak berpengaruh terhadap pengungkapan CSR pada perusahaan high profile di Bursa Efek Indonesia. Tinggi atau rendahnya kepemilikan saham publik dalam perusahaan high profile tidak mempengaruhi dalam pengungkapan CSR. Hal ini dapat diindikasikan kepemilikan saham publik (investor) kemungkinan tidak dilibatkan dalam pengambilan keputusan untuk melaksanakan pengungkapan CSR.

Implikasi dari hasil penelitian adalah investor perlu mendapatkan informasi dari perusahaan agar dapat memberikan informasi pengungkapan CSR adalah seperti Komite Audit, Corporate Governance, Kinerja perusahaan sehingga dapat mempengaruhi dalam pengungkapan CSR. Bagi manajemen perusahaan dapat memberikan pengawasan kepada perusahaan dalam pengawasan agar dapat memberikan informasi kepada investor dan pemilik perusahaan tentang pengungkapan CSR.

\section{PUSTAKA ACUAN}

Agustia, D. (2013). Pengaruh Struktur Kepemilikan Dan Dewan Komisaris Terhadap Corporate Social Responsibility Dan Reaksi Pasar. EKUITAS: Jurnal Ekonomi Dan Keuangan, 17(3), 376-390. https://doi.org/10.24034/j25485024.y2013.v17.i3.2258

Badjuri, A. (2011). Corporate Governance Mechanism, Fundamental Factors, Corporate Social Responsibility ( Csr ) Disclosure Of A Natural Resource And Manufactur Company In Indonesian. Dinamika Keuangan Dan Perbankan, 3(1), 38-54.

Edison, A. (2017). Struktur Kepemilikan Asing, Kepemilikan Institusional Dan Kepemilikan Manajerial Pengaruhnya Terhadap Luas Pengungkapan Corporate Social Responsibility ( Csr ) ( Studi Empiris Pada Perusahaan Sektor Utama Yang Terdaftar Di Bursa Efek Indonesia Tahun 2013 . Jurnal Bisnis Dan Manajemen, 11(2), 164-175.

Fatkhiyatur, R. (2016). Pengaruh Profitabilitas, Ukuran Perusahaan, Kepemilikan Saham Publik Terhadap Pengungkapan Corporate Social Responsibility (Csr). Sekolah Tinggi Ilmu Ekonomi Perbanas, 1-15.

Fifka, M. S. (2015). Pengaruh Struktur Kepemilikan Saham Dan Corporate Social Responsibility Pada Nilai Perusahaan. Corporate Social Responsibilty. Verantwortungsvolle 
Unternehmensführung in Theorie Und Praxis, (1990), 835-848. https://doi.org/10.1097/ HCM.0b013e3181fa050e

Husna, A., Uzaimi, A., \& Trisna, R. (2017). Pengaruh Struktur Kepemilikan Saham, Leverage, Profitabilitas, Ukuran Dewan Komisaris Dan Pertumbuhan Perusahaan Terhadap Pengungkapan Corporate Social Responsibility Pada Perusahaan Manufaktur Yang Terdaftar Di Bursa Efek Indonesia Periode 2013-2015.

Indonesia, R. (2007). UU RI No. 40 Tahun 2007 Tentang Perseroan Terbatas (2007th ed.).

Karima, N. (2014). Pengaruh Kepemilikan Manajerial, Kepemilikan Institusional, dan Kepemilikan Asing terhadap Pengungkapan Tanggung Jawab Sosial Perusahaan. Widya Warta, (2), 219-230.

Maulidra, H. (2015). Pengaruh Struktur Kepemilikan Saham dan Leverage terhadap Corporate Social Responsibility (CSR) (Studi Empiris pada Perusahaan Manufaktur yang Listing di BEI 2010-2012). Ejournal.Unp, 3(1), 1-30.

Melati, P. (2014). Faktor-faktor Yang Mempengaruhi Corporate Social Responsibility (CSR) Studi (Empiris Pada Perusahaan Industri Dasar Dan Kimia Yang Terdaftar Di BEI Periode 2010-2012). Jurnal Ekonomi Universitas MAritim Raja Ali Haji.

Nugroho, M. N., \& Yulianto, A. (2015). Pengaruh Profitabilitas Dan Mekanisme Corporate Governance Terhadap Pengungkapan Csr Perusahaan Terdaftar Jii 2011-2013. Accounting Analysis Journal, 4(1), 1-12.

Nur, M., \& Priantinah, D. (2012). Analisis Faktor-Faktor Yang Mempengaruhi Pengungkapan Csr Diindonesia (Studi Empiris Pada Perusahaan Berkategori High Profile Yang Listing Di Bei). Jurnal Nominal, I(I), 1-13.

Priantana, R. D., \& Yustian, A. (2011). Pengaruh Struktur Good Corporate Governance terhadap Pengungkapan Corporate Social Responsibility pada Perusahaan Keuangan yang Terdaftar di Bursa Efek Indonesia. Jurnal Telaah \& Riset Akuntansi, 4(1), 65-78.

Rahmayanty, S. (2015). Pengaruh Size Perusahaan, Kepemilikan Saham Publik, Kepemilikan Saham Asing, Dan Profitabilitas Perusahaan Terhadap Pengungkapan Corporate Social Responsibility (Csr) Pada Perusahaan Food and Beverages Yang Terdaftar Di Bei Pada Tahun 2010-2013. Jom FEKON, 2(8), 1-12.

Ratmelia, Y. (2015). Profitabilitas Dan Umur Perusahaan Empiris Pada Perusahaan Real Estate And Property Yang Terdaftar Di Bursa Efek Indonesia Pada Tahun 2012-2015. 1-15.

Ratnawati. (2010). Pengaruh struktur kepemilikan saham terhadap kinerja perusahaan. Pengaruh Struktur Kepemilikan Saham Terhadap Kinerja Perusahaan, 1-14.

Rawi. (2008). Pengaruh Kepemilikan Manajemen, Institusi, dan Leverage Terhadap Corporate Social Responsibility pada Perusahaan Manufaktur yang Listing di Bursa Efek Indonesia. Thesis, (Program Pascasarjana Universitas Diponegoro), Semarang.

Rindawati, M. W., \& Asyik, N. F. (2015). Pengaruh Profitabilitas, Ukuran Perusahaan, Leverage, dan Kepemilikan Publik Terhadap Pengungkapan Corporate Social Responsibility (CSR). Jurnal Ilmu \& Riset Akuntansi, 4(6), 2-15. 
Rivandi, M. (2018). Pengaruh intellectual capital disclosure, kinerja keuangan, dan kepemilikan manajerial terhadap nilai perusahaan. Jurnal Pundi, 02(01), 41-54. https:// doi.org/10.1360/zd-2013-43-6-1064

Rivandi, M., \& Gea, M. M. (2018). Pengaruh Mekanisme Corporate Governance Terhadap Ketepatan Waktu Pelaporan Keuangan ( Studi empiris Pada Perusahaan Perbankan Milik Pemerintah Pusat ). Jurnal Akuntansi Dan Pajak, 19(01), 1-9. https://doi.org/ http://dx.doi.org/10.29040/jap.v19i1.167 1.

Rivandi, M., \& Putra, A. H. (2019). Pengaruh Dewan Komisaris Dan Komite Audit Terhadap Pengungkapan Corporate Social Responsibility (Studi Empiris Perusahaan High Profile Di Bursa Efek Indonesia). Jurnal Manajemen Dan Bisnis, 8(1), 128-141. https://doi. org/10.34006/jmbi.v8i1.77

Rochayatun, S. (2016). Faktor-faktor Yang Mempengaruhi Corporate Social Responsibility Disclosure (CSRD). Jurnal Penelitian Ilmu Ekonomi Wiga, 6(1), 63-79.

Sari, A. R., Sutrisno, \& Sukoharsono, E. G. (2013). Pengaruh Kepemilikan Institusional, Komposisi Dewan Komisaris, Kinerja Perusahaan terhadap Luas Pengungkapan Corporate Social Responsibility di dalam Sustainability Report pada Perusahaan Manufaktur yang Terdaftar di BEI. Jurnal Aplikasi Manajemen, 11(3), 481-491.

Soejoto, M. (2017). Pengaruh Struktur Kepemilikan Publik Terhadap Pengungkapan Corporate Social Responsibility Pada Perusahaan-perusahaan Yang Terdaftar Di BEI.

Soliman, M. M., Bahaa-ElDin, M., \& Sakr, A. (2012). Ownership Structure and Corporate Social Responsibility (CSR): An Empirical Study of The Listed Companies in Egypt. International Journal of Social Sciences, 5(1), 63-.

Waryanto. (2010). Pengaruh Karakteristik Good Corporate Governance (GCG) Terhadap Luas Pengungkapan Corporate Social Responsbility (CSR) Di Indonesia. Skripsi, 1-145. https://doi.org/10.1017/CB09781107415324.004

Winarno, W. (2009). Operasional Eviews. Jakarta: Salemba Empat. 